\title{
DESIGN AND SIZING OF STANDALONE SOLAR POWER GENERATION FOR A MEDIUM RESIDENCE IN KANO STATE
}

\author{
Ibrahim KYARI ${ }^{*}$, Jamilu Ya'u MUHAMMAD ${ }^{2}$, Mohammed ABDULLAHI Gele ${ }^{3}$, Abudharr Bello \\ WAZIRI ${ }^{4}$, Anas Abdullahi MUHAMMAD \\ ${ }^{1}$ Department of Electrical and Electronics Engineering, Usman Danfodiyo University, Sokoto, Nigeria \\ ${ }^{2}$ Department of Mechanical Engineering, Bayero University, Kano, Nigeria \\ ${ }^{3}$ Sokoto Energy Research Centre, Services Unit, Sokoto, Nigeria \\ ${ }^{4}$ Department of Mechanical and Production Engineering, Abubakar Tafawa Balewa University, \\ Bauchi, Nigeria \\ ${ }^{5}$ Department of Mechanical Engineering Technology, School of Technology, Kano State Polytechnic, \\ Kano State, Nigeria
}

"Corresponding Author's E-mail: jambcyfm@gmail.com

\begin{abstract}
Energy is one of the prime mover of mankind and need of the energy is always increasing at the same time the sources of energy are depleting with respect to time. Because of these reasons, energy expert thinks of other sources of energy that are sustainable, among which solar energy is the freely renewable energy source and it is abundant in nature. This paper tend to design a stand-alone solar energy generation for a medium house in Kano state Nigeria, the results of the research revealed that a $300 \mathrm{~W}$ solar PV array capacity of 30 modules, $22(140 \mathrm{Ah}, 12 \mathrm{~V})$ batteries and 4 (90A, 202$253 \mathrm{~V})$ voltage regulator are needed to supply the electrical load of the house. The overall cost estimate of the system was $\$ 886,032$ which is relatively high when compared to that of fossil fuel generator used by the house but the payback period of the system is estimated to be 2 years 4 months, which is obviously much shorter than the lifespan of the selected PV modules which is 30 years.
\end{abstract}

Keywords: Battery Bank, Electrical Energy Load, Inverter, Solar PV Module, Voltage Regulator

\section{Introduction}

Due to the high demand of electricity and power fluctuation in most countries in Africa especially Nigeria. Nevertheless, recently around December 2015, the United Nations Framework Convention on climate Change (UNFCCC) Europe led by Paris came up with a Paris Agreement for the world in which countries would devise means and strategies to help curtail global warming to well below $2^{\circ} \mathrm{C}$ by 2030 [1]. One hundred and ninety five countries have signed and agreed to this and Nigeria on $22^{\text {nd }}$ September, 2016 [2]. Scientists and Engineers are always conducting researches on alternative source of generating electricity with consideration of the sustainability of these sources. Solar energy is one of the most promising sources of electricity especially in the northern states of Nigeria due to it's abundant in nature at that states. 
Sunlight is converted in electricity by a means of solar photovoltaic (PV) cell when the light emitted to PV cell that made from silicon $[3,4]$. The power generation by solar cell, the change of temperature and radiation which effect in values of power generation $[5,6]$.

About 1.4 billion people around the world still do not have access to the regular electricity. Almost $85 \%$ of the people without electricity live in rural, semi-urban or remote rural areas of the sub-Saharan Africa and South Asia by estimate [7]. In Nigeria, residential electrification accounts for $57.3 \%$ of the total electricity generated in the Nation, while $26.1 \%$ and $16.6 \%$ account for commercial and industrial use [8].

Although the solar irradiation varies all through the year in Nigeria, it's recorded that the average daily solar irradiation per square meter in Nigeria is about $5.25 \mathrm{kwh}$ with an average estimated sunshine hour of 6.5 hours [9] and receives on the average $20 \mathrm{MJ} / \mathrm{m}^{2}$ per day of solar insolation depending on the time of the year and the location considered $[9,10]$.

There has been an energy policy in place in Nigeria since 2006, called the Renewable Energy Master Plan (REMP). The policy was implemented to increase the share of renewables to account for $10 \%$ of Nigerian total energy consumption by 2025 . The plan includes an installed capacity target of $500 \mathrm{MW}$ by 2025 . Nigeria's power minister has mentioned the ministry aims to boost the installed capacity of solar PV to $1 \mathrm{GW}$ over the next 10 years [8].

\section{Solar Energy Status and Policies in Nigeria}

Solar energy is derived from the ultraviolet radiation given out by the sun from the outer space. It is the pivot of green plants sustenance is it energizes the process of photosynthesis through which green plants manufacture their food. It was claimed that Nigeria is capable of generating up to $600,000 \mathrm{MW}$ of electricity from solar energy from only $1 \%$ of her land area [21]. Solar water heaters have been developed at the National Centre for Energy Research and Development (NCERD) situated at the University of Nigeria Nsukka [22]. Despite the expensive nature of solar power projects, the payback period is said to be not less than 5 years and the panel can last for as long as 25 years. Daily solar radiation is around $3.5 \mathrm{kWh}$ per $\mathrm{m}^{2}$ in southern Nigeria and up to $7.0 \mathrm{kWh}$ per $\mathrm{m}^{2}$ in northern Nigeria [23].

According to a Global Energy Network Institute report: If solar collectors/modules were used to cover $1 \%$ of Nigeria's land area, it would be possible to generate $1850 \times 10^{3} \mathrm{GWh}$ of solar electricity per year. This is over 100 times the current grid electricity consumption level in the country [24]. In a recent study [25], solar integration was classified into grid connected, off-grid hybrid and stand-alone systems. The study reveals that grid connected and off-grid hybrid solar project do not exist in Nigeria. Most of the solar systems projects are either stand-alone mini-grid or off-grid power applications. No comprehensive database exists about Nigerian solar energy applications and projects. Data from various websites and other sources are difficult to harmonize [26]. Although solar thermal power plants are developing on the global scene with some countries investing in the technology due to it benefits, Nigeria has no grid connected thermal power generation system [27]. There have been no solar energy integrated grid systems in the past in Nigeria. Nigeria aims to produce $9.74 \%, 18 \%$ and $20 \%$ of her consumed electricity from renewables by 2015,2020 and 2030, respectively. Solar energy is expected to produce $1.26 \%, 6.92 \%$ and $15.27 \%$ of the electricity consumed in Nigeria by 2015 , 2020 and 2030, respectively [26]. As of 2016, there was no data available to show that the 2015 solar energy targets were met. Over the long term, solar energy is expected to produce $76.36 \%$ of the total electricity consumed [28]. 


\section{Design Method of the System}

After interviewing the householder about the estimation of the house appliances load, the components of the system such as solar photovoltaic, battery bank, inverter, voltage regulator (charge Controller) and cable wires were properly designed and sized.

\subsection{Appliances Loads Estimation}

The house appliances load was presented in the Tab. 1 as:

Table 1. Electrical Energy Load of the House Appliances

\begin{tabular}{|c|c|c|c|c|c|c|}
\hline $\mathbf{S} / \mathbf{N}$ & Name & $\begin{array}{c}\text { Quantity } \\
' Q '\end{array}$ & $\begin{array}{c}\text { Power Rating } \\
\text { 'P' (W) }\end{array}$ & $\begin{array}{c}\text { Usage } \\
\text { Hours 'T' } \\
\text { (Hrs) }\end{array}$ & $\begin{array}{c}\text { Total Power } \\
\begin{array}{c}{ }^{\prime} \mathbf{P}_{\mathbf{t}} \text { ( }(\mathbf{W}) \\
\mathbf{P}_{\mathbf{t}}=\mathbf{Q} \mathbf{P}\end{array}\end{array}$ & $\begin{array}{c}\text { Total Energy } \\
\text { 'E } \mathbf{E}_{\mathrm{t}} \text { ' } \\
(\mathbf{k W h} / \mathbf{d a y}) \\
\mathbf{E}_{\mathrm{t}}=\mathbf{P}_{\mathrm{t}} * \mathbf{T}\end{array}$ \\
\hline 1 & Fluorescents & 50 & 20 & 6 & 1000 & 6 \\
\hline 2 & Television & 5 & 140 & 5 & 700 & 3.5 \\
\hline 3 & DVD Player & 5 & 40 & 5 & 200 & 1 \\
\hline 4 & Fans & 10 & 100 & 6 & 1000 & 6 \\
\hline 5 & Laptop & 3 & 40 & 3 & 120 & 0.36 \\
\hline 6 & Refrigerator & 4 & 140 & 5 & 560 & 2.8 \\
\hline 7 & Pressing Iron & 3 & 1000 & 2 & 3000 & 6 \\
\hline \multirow[t]{2}{*}{8} & Accessories & 4 & 200 & 3 & 800 & 2.4 \\
\hline & Total & & & & 7380 & 28.06 \\
\hline
\end{tabular}

\subsection{Design Assumptions}

In design of an off-grid solar PV system, there are some assumptions and considerations which are employed in the design as:
A. Peak Solar Intensity at the earth surface is taken to be $1 \mathrm{~kW} / \mathrm{m}^{2}$.
B. Inverter converts DC into AC power with efficiency of $90 \%$.
C. The number of the autonomy days is taken to be 2 days.
D. The maximum depth of discharging is assumed to be $50 \%$.
E. The design system voltage is taken to $48 \mathrm{~V}$.
F. The safety factor of the module is taken to be 1.25 .
G. The size of the wires and cables used in this design is considered based on National Electrical Code (NEC).

\section{Selection and Sizing of System}

\subsection{Design and Sizing of Solar PV Module}

Solar photovoltaic module is an electronic device used to convert energy from the sun to useful energy. Before selecting a photovoltaic module for the system, the power output and number of the module were designed and the Yingli $300 \mathrm{Watt}, 24 \mathrm{~V}$ silicon-crystalline module is chosen in this design. 


\subsubsection{Power Output of Solar PV Module}

The power output of the solar photovoltaic module $\left(\mathrm{P}_{p v}\right)$ can be obtained using the relation given by [11]:

$$
P_{p v}=\frac{E_{t} \times P S I}{\eta_{b} \times K_{\text {losses }} \times H_{\text {tilt }}}
$$

Where:

$E_{t}$ is the total daily energy of the house load $=28.06 \mathrm{kWh} /$ day (From Tab. 1);

PSI is the Peak Solar Intensity at the earth surface $=1 \mathrm{~kW} / \mathrm{m}^{2}[11]$;

$\eta_{\mathrm{b}}$ is the Efficiency of the System;

$\mathrm{K}_{\text {losses }}$ is the determination factor due losses on the system such as dust, change in temperature and

$\mathrm{H}_{\text {tilt }}$ is the average solar irradiance falling on the specific tilt angle which is $5.5 \mathrm{~m}$ for Kano metropolis [13].

The efficiency of the system can be found using the relation given by [12] as:

$$
\eta_{b}=\eta_{\text {inverter }} \eta_{\text {connection losses }}
$$

Where:

$\eta_{\text {inverter }}$ is the efficiency of the inverter $=90 \%$ and

$\eta_{\text {connection losses }}$ is the efficiency of the system connection which is between the range $80-90 \%$ [12], and $85 \%$ is taken in this design.

The determination factor can determine using equation given by [11] as:

$$
K_{\text {losses }}=t_{\text {manuf. }} F_{\text {temp. }} F_{\text {dirt }}
$$

Where:

$t_{\text {manuf. }}$ is the manufacturer's tolerance $=97 \%$;

$\mathrm{F}_{\text {dirt }}$ is the de-rating due to dirt which is taken to be $90 \%$ since Kano metropolis is dirty and;

$\mathrm{F}_{\text {temp. }}$ is the temperature de-rating factor which can be found using equation given by [14] as:

$$
F_{\text {temp. }}=1-\left[\gamma\left(T_{\text {cell,eff. }}-T_{S T C}\right)\right]
$$

Where:

$\gamma$ is the power temperature coefficient $=0.48 \% /{ }^{\circ} \mathrm{C}[11]$;

$\mathrm{T}_{\mathrm{STC}}$ is the standard temperature of the collector $=25^{\circ} \mathrm{C}[11]$ and;

$T_{\text {cell, effi. }}$ is the average daily temperature which is given by [14] as:

$$
T_{\text {cell }, \text { eff. }}=25+T_{a}
$$

Where:

$\mathrm{T}_{\mathrm{a}}$ is the ambient temperature $=27{ }^{\circ} \mathrm{C}$. 


\subsubsection{Number of Modules}

The photovoltaic modules were arranged in series and parallel connections.

\section{A. Number of Modules in Series Connection}

The number of modules in series connection can be found using relation given by [15] as:

$$
N_{m s}=\frac{V_{\text {system }}}{V_{\text {module }}}
$$

Where:

$\mathrm{V}_{\text {module }}$ is the nominal voltage of the module $=24 \mathrm{~V}($ Table A1 $)$ and;

$\mathrm{V}_{\text {system }}$ is the designed system voltage $=48 \mathrm{~V}$.

\section{B. Number of Modules in Parallel Connection}

The number of modules in parallel connection can be found using relation given by [15] as:

$$
N_{m p}=\frac{P_{P V}}{N_{m s} P_{\text {module }}}
$$

The number of modules of the system can be obtained by multiplying number of modules in series and that in parallel.

$$
N_{m t}=N_{m s} N_{m p}
$$

\subsection{Design of Battery Bank}

Battery bank is an essential component in smart grid design; it is where the solar irradiance absorbed by the solar photovoltaic modules being stored. The capacity of the battery bank can be obtained using the relation given by [16] as:

$$
C_{b}=\frac{E_{t} N_{c}}{\eta_{i n v .} V_{n} D O D_{\max }}
$$

Where: 
$\mathrm{N}_{\mathrm{c}}$ is the number of the autonomy days $=2$ days;

$\eta_{\text {inv. }}$ is the inverter efficiency $=90 \%$;

$\mathrm{V}_{\mathrm{n}}$ is the nominal battery voltage $=12 \mathrm{~V}$ (Table A2) and;

$\mathrm{DOD}_{\max }$ is the maximum depth of discharging $=50 \%$

The selected battery in this design was lead acid battery made from Hoppecke Solar Power with nominal voltage of $12 \mathrm{~V}$ and capacity of $140 \mathrm{Ah}$. The number of batteries used in this system can found using the equation given by [12] as:

$$
N_{b_{\text {requ }}}=\frac{C_{b}}{C_{\text {selected }}}
$$

Where:

$\mathrm{C}_{\text {selected }}$ is the capacity of the selected battery

Like in solar PV modules, the batteries are also connected in series and parallel arrangement, the number of batteries connected in series can be obtained using the relation given as:

$$
N_{b_{\text {series }}}=\frac{V_{\text {system }}}{V_{\text {battery }}}
$$

Similarly, the number of batteries connected in parallel can be obtained using the relation given as:

$$
N_{b_{\text {parallel }}}=\frac{N_{b_{\text {requ }}}}{N_{b_{\text {series }}}}
$$

\subsection{Design of the Inverter}

An inverter is used in the system where AC power output is needed. The input rating of the inverter should never be lower than the total power of appliances. The inverter must have the same nominal voltage as your battery. For stand-alone systems, the inverter must be large enough to handle the total amount of power that will be using at one time. The inverter size should be $25-30 \%$ bigger than total power of appliances [17].

\subsection{Voltage Regulator Sizing}

According to its function on controls the flow of current. A good voltage regulator must be able to withstand the maximum current produced by the array as well as the maximum load current. Sizing of the voltage regulator can be obtained by multiplying the short circuit current of the modules connected in parallel by a safety factor $\left(f_{\text {safe }}\right)$. The result gives the rated current of the voltage regulator [18].

Where:

$$
I_{\text {rated }}=N_{m p} I_{S C} f_{\text {safe }}
$$

$\mathrm{N}_{\mathrm{mp}}$ is the number of PV modules connected in parallel;

$\mathrm{ISC}_{\mathrm{SC}}$ is the short circuit current of the module and;

$\mathrm{f}_{\text {safe }}$ is the safety factor which is usually taken to be 1.25 [16]. 
doi:

Number of voltage regulator required is given by equation (14):

$$
N_{v_{\text {reg }}}=\frac{I_{\text {rated }}}{I_{\text {selected }}}
$$

\subsection{Sizing of System Cables and Wires}

Selecting the correct size and type of wires and cables will enhance the performance and reliability of a photovoltaic system. Therefore, the National Electrical Code (NEC) was used in selecting cables and wires of this design [19].

\section{Results and Discussion}

\subsection{Results}

\subsubsection{Design Output of Solar PV Module of the System}

Table 2 presents the output parameters of the PV modules of the system as:

Table 2. The output parameters of the PV modules of the system

\begin{tabular}{|c|c|c|}
\hline Input Parameters & Design Calculations & Output Parameters \\
\hline $\begin{array}{l}E_{t}=28.06 \mathrm{kWh} / \text { day; } \\
P S I=1 \mathrm{~kW} / \mathrm{m}^{2} ; H_{\text {tilt }}=5.5 \mathrm{~m} ; \\
\eta_{\text {inverter }}=90 \% ; \eta_{\text {connection }} \\
\text { losses }=85 \% ; t_{\text {man }}=97 \% ; \\
F_{\text {dirt }}=90 \% ; \gamma=0.48 \% /{ }^{\circ} \mathrm{C} ; \\
T_{S T C}=25^{\circ} \mathrm{C} \text { and } T_{a}=27^{\circ} \mathrm{C} .\end{array}$ & $\begin{array}{l}\text { From equation (2): } \\
\qquad \eta_{b}=0.90 \times 0.85=0.768 \\
\text { From equation (5): } \\
\quad T_{\text {cell, } \text { eff. }}=25+27=52^{\circ} \mathrm{C} \\
\text { From equation (4): } \\
\quad F_{\text {temp. }}=1-\left[\frac{0.48}{100}(52-27)\right]=0.8704 \\
\text { From equation }(3): \\
\quad K_{\text {losses }}=0.97 \times 0.8704 \times 0.90=0.76 \\
\text { From equation }(1): \\
P_{p v}=\frac{28.06 \times 1}{0.768 \times 0.76 \times 5.5}=8.74 \mathrm{kWh} / \text { day }\end{array}$ & $\therefore P_{p v}=8.74 \mathrm{kWh} /$ day \\
\hline $\begin{array}{l}V_{\text {system }}=48 \mathrm{~V} ; V_{\text {module }}=24 \mathrm{~V} \\
\text { and } P_{\text {module }}=300 \mathrm{~W} .\end{array}$ & $\begin{array}{l}\text { From equation (6): } \\
\qquad N_{m s}=\frac{48}{24}=2 \text { modules } \\
\text { From equation (7): } \\
N_{m p}=\frac{8.74 \times 10^{3}}{2 \times 300}=14.57 \approx 15 \text { modules } \\
\text { From equation ( } 8 \text { ): } \\
\qquad N_{m t}=2 \times 15=30 \text { modules }\end{array}$ & $\begin{array}{l}\therefore N_{m s}=2 \text { modules } \\
\therefore N_{m p}=15 \text { modules } \\
\therefore N_{m t}=30 \text { modules }\end{array}$ \\
\hline
\end{tabular}



doi:

\subsubsection{Design Output of Solar Battery Bank of the System}

Table 3 presents the output parameters of the solar battery bank of the system as:

Table 3. The output parameters of the solar battery bank of the system

\begin{tabular}{|c|c|c|}
\hline Input Parameters & Design Calculations & Output Parameters \\
\hline $\begin{array}{l}E_{t}=28.06 \mathrm{kWh} / \text { day; } \\
V_{n}=12 \mathrm{~V} ; N_{c}=2 \text { days; } \\
D O D_{\max }=50 \% ; \\
\eta_{\text {inverter }}=90 \% \text { and } \\
C_{\text {selected }}=140 \mathrm{Ah}\end{array}$ & $\begin{array}{l}\text { From equation (9): } \\
\qquad C_{b}=\frac{28.06 \times 10^{3} \times 2}{0.50 \times 0.96 \times 12}=9743 \mathrm{Ah} \\
\text { From equation (10): } \\
\qquad N_{b_{\text {requ }}}=\frac{9743}{140}=69.6 \approx 70 \text { batteries }\end{array}$ & $\begin{array}{l}\therefore C_{b}=9743 A h \text { and } \\
N_{b_{\text {requ }}}=70 \text { batteries }\end{array}$ \\
\hline $\begin{array}{l}V_{\text {system }}=48 \mathrm{~V} \text { and } \\
V_{\text {battery }}=12 \mathrm{~V}\end{array}$ & $\begin{array}{l}\text { From equation (11): } \\
\qquad N_{\text {bseries }}=\frac{48}{12}=4 \text { batteries } \\
\text { From equation (12): } \\
N_{\text {bparallel }}=\frac{70}{4}=17.5 \text { say } 18 \text { batteries }\end{array}$ & $\begin{array}{l}\therefore N_{b s}=4 \text { batteries } \\
\therefore N_{b p}=18 \text { batteries }\end{array}$ \\
\hline
\end{tabular}

\subsubsection{Design Output of Voltage Regulator of the System}

Table 4. presents the output parameters of the voltage regulator of the system as:

Table 4. The output parameters of the voltage regulator of the system

\begin{tabular}{|l|l|l|}
\hline Input Parameters & Design Calculations & Output Parameters \\
\hline $\begin{array}{l}N_{m p}=25 \text { modules; } \\
f_{\text {safe }}=1.25 ; I_{S C}=5.38 \mathrm{~A} \text { and } \\
I_{\text {selected }}=90 \mathrm{~A}\end{array}$ & From equation (13): & \\
& $I_{\text {rated }}=25 \times 9.6 \times 1.25=300 \mathrm{~A}$ & $\therefore I_{\text {rated }}=300 \mathrm{~A}$ and \\
& $\begin{array}{c}\text { From equation (14): } \\
N_{v_{\text {reg }}}=4 \text { Regulators }\end{array}$ \\
& & \\
& & \\
& &
\end{tabular}




\subsubsection{Cost Estimation and Analysis}

a) Estimated Cost of the System

Table 5. presents the estimate cost of system's components as

Table 5. The estimate cost of system's components

\begin{tabular}{|c|c|c|c|c|}
\hline Components & Model & Quantity & Unit Price ( & Overall Cost ( \\
\hline Solar Modules & $\begin{array}{l}\text { Yingli } 300 \mathrm{~W}, 24 \mathrm{~V} \\
\text { (Silicon- } \\
\text { crystalline } \\
\text { Technology) }\end{array}$ & 30 & 24,500 & 735,000 \\
\hline Battery & $\begin{array}{l}\text { Hoppecke } \\
\text { Solar.power } \\
\text { 140Ah, 12V (Lead } \\
\text { Acid Type) }\end{array}$ & 22 & 4,000 & 88,000 \\
\hline Inverter & $\begin{array}{l}\text { Latronics LS- } \\
3000 \mathrm{~W}, 24 \mathrm{~V} \text { (d.c), } \\
220 \mathrm{~V} \text { (a.c). }\end{array}$ & 2 & 6,000 & 12,000 \\
\hline $\begin{array}{l}\text { Voltage } \\
\text { Regulator }\end{array}$ & $\begin{array}{l}\text { Sunny Island 202- } \\
253 \mathrm{~V}, 90 \mathrm{~A}\end{array}$ & 4 & 3,500 & 14,000 \\
\hline $\begin{array}{l}\text { Miscelleneous } \\
\text { Cost }\end{array}$ & & & & 30,000 \\
\hline Total & & & & 879,000 \\
\hline
\end{tabular}

The operating costs for solar PV installations are negligible, but the annual maintenance cost may amount to $0.5 \%$ to $1 \%$ of the capital cost of the system. Maintenance cost of the PV system is taken to be $0.8 \%$ of the capital cost of the system as:

$$
\text { Annual Maintenance Cost }=0.8 \% \times \text { Capital Cost }=0.8 \% \times \$ 879,000=\$ 7032
$$

Therefore, the overall cost of the system can be found by adding the capital cost of the system with annual maintenance cost as given below:

$$
\text { Overall cost }=\text { capital cost }+ \text { annual maintenance cost }=\mathrm{N879,000+ \$ 7032=} \$ 886,032
$$

The house has a small generator used to charge the batteries of the system when there is no sun for a day.

The hours estimated was 3hours per day,

The total estimated hours used per annum were:

$$
\text { Total estimated hours per annum }=3 \times 365=1095 \text { hours }
$$

The estimated fuel (Petrol) used for the generator was two litres per hour; 
The total estimated fuel consumed by the generator per annum was:

Total estimated fuel consumed per annum $=1095 \times 2=2190$ litres

The prevailing market price for a litre of petrol for running a generator in Nigeria was at the rate of \$145 per litre [20].

The total cost fuel consumed by the generator per annum was:

$$
\text { Total estimated cost fuel consumed per annum }=2190 \times 145=\$ 317,550
$$

For the generator to work properly it needs maintenance regularly, therefore the estimated maintenance cost of the generator was $\$ 15,000$.

The total running cost of the generator per annum was:

$$
\text { total running cost }=\$ 317,550+\$ 15,000=\$ 332,550
$$

The cost of purchased of the generator was $\$ 46,800$;

Finally, the cost of the petrol consumed and the cost of generator for the first year was:

Total running cost and cost of the generator $=\$ 332,550+\$ 46,800=\$ 379,350$

\section{b) Payback Period of the System}

The payback period of the system was equal to the ratio of the overall cost of the solar PV system to the total running cost of the fuel and cost of the generator.

$$
\begin{gathered}
\text { Payback Period }=\frac{\text { Overall cost of the solar PV system }}{\text { total running cost fuel and cost of the generator for the } 1 \text { st year }} \\
\text { Payback Period }=\frac{N 886,032}{\mathrm{N379,350}}=2.34 \text { years }=2 \text { years } 4 \text { months }
\end{gathered}
$$

\subsection{Discussion of the Results}

The system was design and sizing the system components by considering the daily electrical energy demand for the house. The load was estimated as $28.06 \mathrm{kWh} /$ day based on the watt-hour rating of the appliances. The result of the estimated daily electrical energy demand was presented in Table 2.1. The stand-alone solar PV system was designed based on the estimated load.

The results as shown in Table 4.1 show that the house requires 30 solar PV which consist of series and parallel connections of the solar PV arrays of 2 modules and 15 modules respectively and Yingli mono-crystalline solar PV with output of $300 \mathrm{~W}, 24 \mathrm{~V}$ was selected in order to generate electrical energy $8.74 \mathrm{kWh} /$ day to the house.

For storage of energy for use when there is demand a storage battery bank has been designed and selected. From Table 4.2, the house requires 22 batteries of which 18 are connected in parallel while 4 
batteries are connected in series. A battery bank with a capacity 140Ah manufactured by Hoppecke Solar Power was selected.

To safely charge the batteries and to maintain longer lifetime for them, the house requires a voltage regulators of capacity 90A. But the some of the appliances are AC current appliances, so the house requires inverters that convert its $\mathrm{DC}$ current to $\mathrm{AC}$ current. The number of the inverter required by the system is only one.

Finally, the capital cost of the system was $\$ 879,000$ whereas the overall cost of the system was $\$ 886,032$. It was observed that the modules, the batteries and the inverter are the most costly components of an off grid photovoltaic system (Table 4.4). Increasing the size of these components will increase the overall cost of the system. A cost estimate of the system provides the payback period of the system is estimated to be 2 years 4 months which is obviously much shorter than the lifespan of the solar PV modules which is 30 years (Table A1).

\section{Conclusion and Recommendation}

In this research work, the electrical energy demand of a house in a rural area of Kano state, Nigeria was estimated as $8.74 \mathrm{kWh} /$ day. System design, sizing and selection of the components were provided based on the estimated load. The results of the research revealed that a $300 \mathrm{~W}$ solar PV array capacity of 30 modules, $22(140 \mathrm{Ah}, 12 \mathrm{~V})$ batteries and $4(90 \mathrm{~A}, 202-253 \mathrm{~V})$ voltage regulator are needed to supply the electrical load of the house. The overall cost estimate of the system was $\$ 886,032$ which is relatively high when compared to that of fossil fuel generator used by the house but the payback period of the system is estimated to be 2 years 4 months, which is obviously much shorter than the lifespan of the selected PV modules which is 30 years. The recommendation would be that the system can be made utility- interactive to enable the purchase of surplus solar energy from users.

\section{References}

[1] Paris Agreement. Available at https://ec.europa.eu/clima/policies/international/negotiations/paris en.

[2] Buhari signs Paris Agreement on Climate Change. Retrieved from https://www.businessdayonline.com/buhari-signs-paris-agreement-on-climate-change/.

[3] Shneen, S. W., Advanced Optimal for PV system coupled with PMSM. Indonesian Journal of Electrical Engineering and Computer Science, 1 (2016), 3, pp. 556-565.

[4] Jaafar A. K., Exploitation of solar energy in the process of purification of the land surface water, International Journal of Computation and Applied Sciences IJOCAAS. 5 (2018), 1, pp. 356360.

[5] Shneen, S. W., Advanced Optimal for Power-Electronic Systems for the Grid Integration of Energy Sources. Indonesian Journal of Electrical Engineering and Computer Science. 1 (2016), 3, pp. 543-555.

[6] Jaafar A. K., Design and Construction of a Tracking Device for Solar Electrical Systems. Journal of Scientific and Engineering Research. 5 (2018), 7, pp. 225-236.

[7] Ramchandra P., Financing LED solar home systems in developing countries. Renewable and Sustainable Energy Reviews. 25 (2013), pp. 596-629. 
[8] Unlocking Solar Capital Africa, $1^{\text {st }} \& 2^{\text {nd }}$ November, 2016. Nairobi, Kenya. Available at: http://sun-connectnews.org/fileadmin/DATEIEN/Dateien/New/Solar_Facts_Figures_Africa.pdf.

[9] Michael et al., Exploring the Economic and Environmental Benefits of Solar Energy Generation in Developing Countries: The Nigerian Perspective. Journal of Energy Technologies and Policy. Retrieved from, http://www.iiste.org/Journals/index.php/JETP/article/viewFile/6460/6559.

[10] Abe A. and Adetan O., Development of solar systems in Nigeria: Challenges and Prospects. Proceedings of the $1^{\text {st }}$ National Engineering Conference on Sustainable Energy Development in Nigeria: Challenges and Prospects. Faculty of Engineering, University of Ado Ekiti, Nigeria. (2008), pp. 94 - 98.

[11] Ahmad, G. E. Photovoltaic - powered Rural Zone Family House in Egypt. Renewable Energy, 26 (2002), pp. 379-390.

[12] Ishaq M., et al., Design of an Off Grid Photovoltaic System: A Case Study of Government Technical College, Wudil, Kano State. International Journal of Scientific and Technology Research, 2 (2013), 12, pp. 175-181.

[13] Kano Metrological Centre (2019). Aminu Kano International Airport, Kano State, Nigeria.

[14] Clean Energy Council (CEC) (2009). “Grid Connected PV Systems Design Guidelines for Accredited Designers" Issue 3 July 2007, Update November 2009.

[15] Sandia, Stand-Alone Photovoltaic Systems: A Handbook of Recommended Design Practices, Sandia National Laboratories Albuquerque New Mexico, 1995.

[16] Assad A., A Stand Alone Photovoltaic System, Case Study: A Residence in Gaza, Journal of Applied Sciences in Environmental Sanitation, 5 2010, pp. 81-91.

[17] Sopian, K., et. al., A stand-alone Photovoltaic System Design and Sizing: a Greenhouse Application in Sabha City: Case study in Libya. Proceeding of the $3^{\text {rd }}$ Engineering Science and Technology. International Conference (ESTIC) 2016, Padang Indonesia August, $30^{\text {th }}-31^{\text {st }}$ 2016.

[18] Al Dulaimi, N. H., Design of an Off-Grid Solar PV System for a Rural Shelter. M. Sc. Thesis, German Jordanian University, School of Natural Resources Engineering and Management, Department of Energy Engineering, 2017.

[19] National Electrical Code (NEC, 2005).

[20] Nigerian Private Oil Marketers Hike Price of Petrol. Retrieved from: http://www.nigerreporters.com/nigerian-private-oil-marketershike-price-of-petrol/.

[21] A Review of the Nigeria Energy Industry, $3^{\text {rd }}$ October, 2011. http://www.thisdaylive.com/articles/nigeria-can-generate-600-000mw-from-solar-energy-/99738/

[22] Ilenikhena, P. \& Ezemonye, L. WEC Montreal 2010. www.worldenergy.org/documents/congresspapers/135

[23] Goudarzi, S. 2008. Journal of Renewable and Sustainable Energy. www.jrse.aip.orgII.2182594

[24] Global Energy Network Institute - GENI - Global electricity grid - linking renewable energy resources around the world. 2014. Retrieved from: http://www.geni.org

[25] Ohunakin, O. S.; Adaramola, M. S.; Oyewola, O. M.; Fagbenle, R. O. Solar energy applications and development in Nigeria: drivers and barriers. Renewable and Sustainable Energy Review. 2014; 32: 294-301.

[26] Ozoegwu, C. G.; Mgbemene, C. A.; Ozor, P. A. The status of solar energy integration and policy in Nigeria. Renewable and Sustainable Energy Review. 2017; 70: 457-71. 
[27] Tian, Y and Zhao, C. Y. A review of solar collectors and thermal energy storage in solar thermal applications. Applied Energy. 2013; 104: 538-53.

[28] Energy Commission of Nigeria. Draft of national renewable energy and energy efficiency policy. 2014. Available from: http://www.energy.gov.ng/

\section{Appendix}

Table A1: Solar PV Module Specification

\begin{tabular}{|ll|}
\hline Manufacturer & Yingli \\
\hline Type & Silicon-Crystalline Technology \\
\hline Rated Power (Watts) & 300 \\
\hline Nominal Voltage (Volts) & 24 \\
\hline Nominal Current (Amperes) & 9.16 \\
\hline $\begin{array}{l}\text { Short Circuit Current } \\
\text { (Amperes) }\end{array}$ & 9.6 \\
Open Circuit Voltage (Volts) & 40.1 \\
\hline Lifespan (years) & 30 \\
\hline
\end{tabular}

Table A2: Solar Battery Bank Specification

\begin{tabular}{ll}
\hline Manufacturer & Hoppecke Solar.Power \\
\hline Battery Capacity (Ah) & 140 \\
\hline Battery Type & Lead Acid \\
\hline Nominal Battery Voltage (V) & 12 \\
\hline Daily Amperes-Hours needed & 1576 \\
\hline
\end{tabular}

Table A3: Voltage Regulator Specification

\begin{tabular}{|ll}
\hline Manufacturer & Sunny Island \\
\hline Nominal Voltage (V) & Adjustable (202-253) \\
\hline Maximum Continuous Power (W) & 2200 \\
\hline Input Voltage Range (V) & $(172.5-264.5)$ \\
\hline Charge Controller Type & MPPT \\
\hline Battery Capacity & $(100-10000) \mathrm{Ah}$ \\
\hline Maximum Battery Charging Current (A) & 90 \\
\hline Battery Voltage Range(V) & $(16.8-31.5)$ \\
\hline Charge Controller Efficiency & $93 \%$ \\
\hline
\end{tabular}

